\title{
Tense situations and the significance of stability for psychological security
}

\author{
Aleksander I. Dontsov ${ }^{\star}$, Elena B. Perelygina ${ }^{* *}$ \\ ${ }^{*}$ Lomonosov Moscow State University, Moscow, Russia \\ ${ }^{* *}$ Liberal Arts University - University for Humanities, Yekaterinburg, Russia
}

\begin{abstract}
Present reality gives rise to contradictory trends: the combination of new threats, tense situations, and destructive tendencies shapes awareness of the importance of identifying, assessing, and managing emerging situations and of developing new scientific paradigms. The polyfunctional interpretation of psychological security correlates with the perception of stability as a specific arrangement of interactional processes and the relatedness of stereotypes, standards, sociocultural attitudes, and social perceptions. A tense situation clearly indicates the separation of the potential of the person and the group from the notion of subject-action in security promotion and maintenance. The depersonification of social institutions is accompanied by each person's growing attention to himself/herself and the increasing significance of this kind of attention in overcoming uncertainty and tension.

The process of making decisions in a tense situation often includes the phenomenon of the illusion of control over the situation, which can pose a threat to psychological security. The social significance of the promotion of psychological security calls for consolidation of efforts aimed at the stability of the society and the prevention of stress-producing situations.
\end{abstract}

Keywords: tense situations, subject of psychological security, dynamic stability, social perceptions, social and psychological consequences of the terrorist threat

Current trends in the transformation of social reality call for changes in the perception of psychological security, an analysis of new situations, and the development of new scientific paradigms. In the twenty-first century, the new institutionalization can be based on the analysis and prevention of challenges, hazards, threats, and risks to national goals, social ideals, and core values of the individual, family, organization, state, and society. In its new way, Russia encounters modified and new risks, threats, and challenges affecting the basic safety of our society in its different manifestations, forms, and levels.

In the present environment, which is characterized by an array of threats unprecedented in their scale, depth, and intensity, the concept of psychological secu- 
rity has moved up to the level of research, which is essential for understanding the impact these threats have on the individual and their significance for changes in the motivation and value paradigms typical of social groups, for identifying ways of preventing personal destruction, and for studying changes in social relationships. "A crisis-induced environment affects the interaction between the person and society, making it strained, conflicting, unclear in its social consequences. "A person's consciousness and behavior go through deformation in a society affected by a crisis" (Zinchenko \& Zotova, 2010, p. 45). Information wars, economic contradictions and political conflicts, and the growing significance of the Internet are redefining the focus of research attention in psychology.

The globalization of communication processes has spotlighted such aspects as the subject-subject relationship, "feedback", and the symbolic context of social interaction.

At the level of meanings, concepts, texts, values, i.e. everything that does not pertain not to qualities, but to contents that people can exchange, while also interacting with culture and sociocultural communities, we are basically disconnected, we exchange these contents all the time. This constitutes the dialogic nature of human existence. (Leontiev, 2009, p. 99).

The conceptual reevaluation of communication as a specific sociocultural phenomenon is especially important in the present context, as the process of globalization places a special emphasis on the dialogue between countries and people. In this new situation, "intersections" of cultural fields are becoming increasingly diversified. In the present environment, the level of an individual's development and his or her ability to decode texts depend to a large extent on his or her involvement in the network society (Castells, 2000, p. 105). Thus, both communication and interactivity become dependent on the level of expertise in modern information technology. The new communication space is still going through the stage of development, and the potential consequences of this process remain unclear in many ways. At the same time, undoubtedly, the Internet and virtual reality, which constitute basic elements of the new world of communication, feature a conceptual shift both in perceptions and in the understanding of the world.

These conditions are characterized by the dramatically increased scale of interrelationships and the extent of interdependence in modern society. These processes are so intensive and obvious in social communities and movements, countries and continents, multinational corporations and emerging markets that today's society is turning into a "network" society, where the core is represented by the global economy. This economy in contrast to the hierarchical model of the world economy described by F. Braudel and I. Wallerstein "operates as a single system in real-time mode throughout the planet” (Castells, 2000, p. 105).

The confrontation of the basic components of the problem brings two trends to the forefront. The first trend is connected to growing threats, crisis situations, and the destructive potential of the ongoing transformations; the second trend is connected to the minimization of the effect of these threats and crises and the search for efficient methods of controlling the forms and mechanisms of stability. From the perspective of the functional paradigm, the subject of psychological security is seen as an open-ended system communicating with the environment and thus 
imparting dynamics to stability. Non-equilibrium and instability are no longer seen as destructive and negative. The transition from the equilibrium condition to the unstable, non-equilibrium one brings forth a new, previously unknown pattern. These approaches to conceiving security in the context of the dialectical interaction between the tension of situations and their stability suggest(1) the possibility of scientifically analyzing psychological security through the possibility of overcoming threats, (2) the importance of stability, and (3) the significance of stabilizing mechanisms for alleviation of tension in the subject-action domain and in the social perception of danger.

The concern about escalating tension in different economic, political, sociocultural, and external situations is clearly outlined in an article by V. Putin. The president of the Russian Federation states:

"We are witnessing more and more often new regional and local wars. There are new zones of instability and artificially fuelled, controlled chaos. There are purposeful attempts to provoke such conflicts in close vicinity to the borders of Russia and our allies. We can see the devaluation and destruction of the basic principles of international law, especially in the sector of international security." (Putin, 2012, p. 2)

The devaluation of the principles of international security results in deformation of concepts and polyfunctional interpretation of the content of psychological security. Stability incorporates an array of interactional processes, relevance areas, correlation of sociocultural positions, socially approved types, and social perceptions. Increased tension is perceived by a person as the possibility of emerging anomie and destruction, as the likelihood of deformation of the person's objectives and role-play positions, as the separation of the individual level of attainability and the specific systems of relevance.

The modern period triggered the trend toward the differentiation of possibilities, the separation of the potential of the person, groups, and organizations from subjectivity in perception and the promotion of security. Addressing the issues discussed at the World Political Forum (Yaroslavl, September 9-10, 2010), foreign scientists pointed out:

"The period of modernity ushered in new social relationships that were no longer directly associated with cultural, religious and even global realities; instead, these relationships were perceived in the contractual context. ... The spirit of "proprietary individualism," typical of modernity, gave birth to "acquisitive societies." ...In the establishment of states, the emphasis shifted from the supranational division of power to monopolization of legitimate power by national monarchs. Changes in the nature of war contributed to further rapprochement of kings and oligarchs: the latter provided income to the former in return for protection and security. This process gave rise to a new idea that became the quintessence of the period of modernity - the idea of the eternal, territorial, depersonalized state. (Pabst, 2010, pp. 234-236)

In the modern age, the depersonification of social organizations does not eliminate sources of and grounds for tense situations that affect the individual. In the first century of the new era Seneca wrote, "Safe time does not exist. Pains stem 
from delights; wars break out during peaceful times and pillars of security turn into islands of fear; the friend becomes the foe, the ally partner becomes the enemy" (Seneca, 1986, p. 201). The tendency toward the depersonalization of the state during the modern period may deepen the significance of personal values, preferences, experiences, and perceptions.

In recent times psychology, led by philosophical science, has actively assumed responsibility for the classification of scientific approaches, which provides the foundation for the following types (and stages) of the development of scientific knowledge: classical, nonclassical, and post-nonclassical. The contemporary state of scientific knowledge is generally believed to be characterized by the concept of post-nonclassical science. (Zinchenko \& Pervichko, 2012, p. 158).

Although present-day skeptics and alarmists still cannot come to agreement, postmodern theories highlight the "self-concern" of the person and the importance of coping in overcoming instability and uncertainty and in alleviating the intensity of strain and protecting the individual amidst global exposures.

A theoretical analysis of the nature of social situations in present-day Russian society reveals different forms of social contradictions and conflicts; volatility and stability have alternated with each other since the early 1990s, entering into combinations and forming fanciful symbioses. Social-philosophical and historical-psychological studies show that periods of radical social reforms inevitably give rise to new or modified forms of group consciousness, social perceptions, and ideological collisions. One of the theoretical classifications of these processes and situations is transformation changes, "the so-called 'unstable equilibrium' represented by alternating periods of partial or minor 'adjustments' [and] drastic changes" (Yemelyanova, 2009, p. 85).

Different forms of people's experiences of unstable situations are connected with collisions between tradition and new trends during the social and economic, cultural and historical process. According to Vasilyuk (1984), these forms of experiences can develop in two directions: negative ("failure") and positive ("success"). A person's negative experiences of an unstable situation are aimed at elimination, prevention, or alleviation of discontent, thus saving the person from commotion, giving him or her time to prepare other, more effective ways of responding. The negative experiences offer a selective choice of behavioral patterns without taking into account the entire situation and its cause-and-effect grounds.

The positive experiences of an unstable situation, which are notable for the application of the adaptive potential of the person, work as a focused process. The positive experiences of an unstable situation focus on the acknowledgement and acceptance of reality, the active evaluation of the actual situation, its comprehensive analysis, and an active search for and acceptance of assistance. The positive ("successful") experiences of an unstable situation provide organized and controlled satisfaction of needs and impulses, promote accumulation of individual experience in "mastering" real-life situations, and help to overcome the distress caused by inability to implement some instinctive programs of behavior (Vasilyuk, 1984, pp. 21-22). Such programs can be targeted at overcoming natural biological or social needs connected with intra- and intergroup relationships (such as competition and aspiration for dominance, subordination to the higher-ranking members of a 
social group, group solidarity as important for "altruistic" actions of members of the group and for its overall survival).

The present environment offers new grounds for desynchronization and destabilization of the social and behavioral situation, the nature of expectations, the level of tension, and psychological security. There are passive and active components of people's experiences of unstable situations. The passive component is associated with experiencing one's actual existence as full of misfortune, fear, and sufferings. The active component manifests itself as seeking change in the state of things, focusing on positive experiences. The positive experiences of tense situations result from the impact of hostile natural, social, or supernatural forces on the person, and active experiencing of tense situations turns into the source and the cause of the social actions performed by a person, actions that are aimed at the achievement of stability.

Garfinkel (1963) pointed out that in interactional situations a person undertakes perceptive and rationalizing efforts to increase the stability of interpersonal environments and situations, to prevent anxiety and strains, to "normalize" events. "By 'normalize,' I mean restoration of perceivably normal parameters of typicality, comparability, likelihood, causal texture, instrumental effectiveness and strict utility" (Garfinkel, 1963, p. 189).

An analysis of emergency situations shows that their social and psychological factors and consequences lack scientific attention adequate to their significance. For example, Tarabrina and Bykhovets (2011) state:

The social and psychological consequences of terrorist threats include victimization, antisocial behavior, rental behavior, alcoholization, family conflicts, stigmatization and discrimination, academic underperformance, aggravation of social conflicts in society.... The social and psychological consequences of terrorist threats are manifested in citizens' disbelief in the ability of the state (the government) and its law-enforcement agencies to protect people.

The epistemology of psychological security involves the analysis of not only obvious but also hidden connotations. The theoretical comprehension and rational "awareness" of a tense situation in the form of interpretation make a contribution to the systematization of the problems as they correlate with the stability of everyday life and the social environment.

The realities of the twentieth century posed the problem of equilibrium and stability in society in the context of perceived personal responsibility and personal choice. Unstable situations can cause deformation in the dialogical connection between the opportunity and reality; they can intensify the role and significance of the conscious, action-focused individual in conceiving, differentiating, and implementing opportunities and in assuming responsibility for his/her choice. When people are confident that they are free to choose the behavior pattern that is the direct expression of their own objectives and attitudes, social processes start developing in a totally different way than they do when people think they are being made to behave like that or when their actions are governed by economic incentives or external organizations. 
The problem of experiencing unstable situations at the personal level calls for the identification of psychological mechanisms for protecting the individual against such situations. The direct objective of such protection mechanisms is to achieve the maximum emotional well-being possible in such situations. In the opinion of many scholars, protection mechanisms are required for the integration of the self and satisfy the requirement of the self in synthesis and harmony, which are often deemed as an independent motive for psychological protection.

Harmony in interpersonal communication is based on reciprocal relationships, "as the symbolic structures of the living world reproduce themselves in the form of cultural tradition, social integration and socialization, and these processes...can be implemented only through an action aimed at mutual understanding" (Habermas, 2000, p. 161).

Experiences of unstable situations in their subject-subject perception and interaction must and can be based on impartiality and consistency of moral principles, standards, assessments, and mutual satisfaction of interests in the process that George H. Mead referred to as the "universal discourse."The specifics of the moral principles that determine experiences of unstable situations were analyzed by I. Kant, who wrote that the moral principle invalidates standards that cannot be approved by everyone involved, and only those standards that express unanimous will can be accepted (Habermas, 2000, p. 100); these principles secure harmony and harmonization of social relationships.

Today, the implementation of moral principles that govern the process of experiencing unstable situations has been impeded because of the growth of social hedonism, the pursuit of entertainment and delight, and the attempt to avoid social problems. In this context, the instability of a social situation is caused by the conflict between economic growth rates and consumption growth rates; this conflict is accompanied by the rapid advancement of consumption psychology and changes in consumer values.

These characteristics are especially glaring during economic crises, when people are driven by beliefs and stereotypes in making rational financial decisions. Positive attitudes during a period of economic stability or recovery play a crucial role in making decisions based on confidence in success. The rational analysis of information can be ignored or rejected. Economic publications offer simulation models for different economies, taking into account not only econometric data but also the economic sentiment index and the population's confidence level; in the opinion of foreign scholars, the confidence level is inseparably connected with the economic situation and can cause social-economic instability when it moves down.

Conventional laboratory experiments designed to examine an individual's experiences in unstable or tense situations or to study trust or defense mechanisms quickly call into question the researcher's moral principles as well as the moral and legal basis for such investigations. Andreeva (1975) notes:

Thus the problem takes yet another, somewhat curious turn: the connection between the methodological difficulties encountered when utilizing experiments in social psychology and moral and ethical questions. ... The "complications," in moral and legal 
terms, of sociopsychological experiments are recognized even by researchers who are far removed from such explicit methodological skepticism regarding the experimental method in social psychology. (p. 286)

However, an examination of specific data and their changes is of great importance for pertinent social and psychological research, and so we turn to published materials on the ranking of fears held by Russians, as analyzed in the journal New Times. The data obtained from the study are given in Table 1.

The debate in the psychological literature about the nature and meaning of fears, their affective basis, and their inversely proportional tie to the work of the intellect shows the functional significance of fears for controlling the behavior of the masses and large groups of people. Among the specifics of behavior that can threaten psychological security and generate tense situations and crises, the phenomenon of the illusion of control is fairly widespread. The transfer of rules and patterns that regulate a situation on a rational, substantively transformative level, in which the result is largely out of one's control, creates a belief in certain symbols and rituals and in the fact that a successful result is the result of an individual's abilities to effectively analyze information and make the needed decisions.

Over the course of research conducted in October 2012 with managers, entrepreneurs, and mid-level executives $(\mathrm{N}=128)$ in Yekaterinburg and the town of Revda (the Sverdlovsk region), an informational and meaningful assessment of a situation and a set of information blocks were given to the participants; from this information, they created their own information structures. Within 10 minutes of a single additional block of information being introduced and discussed, $16 \%$ of the managers, $8 \%$ of the entrepreneurs, and $5 \%$ of the mid-level executives adjusted their evaluation. Once a second additional block of informa-

Table 1. Changes in the Ranking of Russians' Fears (1991-2006)

\begin{tabular}{clcc}
\hline Rank & \multicolumn{1}{c}{$\begin{array}{c}\text { Nature and subject } \\
\text { of the fear }\end{array}$} & $\begin{array}{c}\text { \% of those } \\
\text { surveyed } \\
\text { in 2006 }\end{array}$ & $\begin{array}{c}\text { \% of those } \\
\text { surveyed } \\
\text { in 1991 }\end{array}$ \\
\hline I. & $\begin{array}{l}\text { Fear of losing loved ones } \\
\text { Absence of any kind of fear }\end{array}$ & 54 & 45 \\
II. & Fear of war or large-scale massacres & 5 & 5 \\
III. & Fear of hunger & 43 & 53 \\
IV. & Fear of governmental tyranny & 22 & 32 \\
& Fear of bureaucratic tyranny at the hands of officials & 60 (approx.) & 16 \\
V. & Fear of death & 8 & - \\
VI. & Fear of a public affront & 7 & 9 \\
\hline
\end{tabular}

Note. Data from What We Fear Most of All. A Scale of Fears, 2007, retrieved from http://psihology. net.ru/chego-my-boimsya-bolshe-vsego-rejting-straxov/

a Primarily men under the age of 29 with an elementary or highschool education. 
tion was introduced and discussed, a delayed reaction was seen with in another 10 minutes. This time $13 \%$ of the managers, $11 \%$ of the entrepreneurs, and $7 \%$ of the mid-level executives changed their impression of the situation. These results are the effect of conservatism (a conservatism bias).The data obtained require further verification, but there was a tendency for the managers to become immunized against a change in the amount and content of information. It is telling that both entrepreneurs and mid-level executives, who bear organizational and economic responsibility for decision-making, exhibited less conservatism and more fluidity than the managers.

The study conducted with the same group of respondents on the phenomenon of the illusion of control showed that $57 \%$ of the men were willing to transfer rational assessments to the realm of probability and were confident of the accuracy of their conclusions. Only $33 \%$ of the women showed a desire for such extrapolation and such certainty in their own judgment. Confidence in one's competence and in the accuracy of one's prognostic evaluations is closely tied to the risk involved in the decision, to which the men were more inclined.

The data obtained are quite important for what they indicate about making decisions in a tense situation or crisis. Both the illusion of control over the situation and the effect of conservatism with delayed decisions pose a threat to the security of an individual, a group, or the social environment, depending on the content and scope of the decision.

Schneier (2008) offers a substantive explanation for the occurrence of such errors in evaluations of dangerous situations: "Danger is ... a matter of perception as well as reality. And these are not the same thing." He shows that real security can be calculated mathematically as well as by taking into account the various risks and the effectiveness of the decisions that are made. However, it is psychologically important whether an individual feels secure and whether he or she perceives the situation as safe, given all the risks and decisions. A number of areas of research provide important material for examining these issues.

Four fields of research - two very closely related-can help illuminate this issue. The first is behavioral economics, sometimes called behavioral finance. Behavioral economics looks at human biases-emotional, social, and cognitive-and how they affect economic decisions. The second is the psychology of decisionmaking, and more specifically bounded rationality, which examines how we make decisions. Neither is directly related to security, but both look at the concept of risk: behavioral economics more in relation to economic risk, and the psychology of decision-making more generally in terms of security risks. But both fields go a long way to explain the divergence between the feeling and the reality of security and, more importantly, where that divergence comes from.

There is also direct research into the psychology of risk. Psychologists have studied risk perception, trying to figure out when we exaggerate risks and when we downplay them.

A fourth relevant field of research is neuroscience. The psychology of security is intimately tied to how we think: both intellectually and emotionally. Over the millennia, our brains have developed complex mechanisms to deal with threats. 
Understanding how our brains work, and how they fail, is critical to understanding the feeling of security. (Schneier, 2008)

Many scholars highlight the interdisciplinary nature of the problems of psychological security; however, we note that the psychology of decision-making and the psychology of risk designated by Schneier have not been thoroughly developed by conceptual approaches in Russian science of psychology.

In addition, the psychological concept of risk is extremely pertinent today to the search for ideas and answers to the problem of deepening threats to human security. By making a detailed analysis of the concept of ruptures in historical development, Martinelli (2006) shows that the particular characteristics of contemporary society create risks awareness and cause risks to appear in different areas.

Because of the danger of new, previously impossible global catastrophes, such as nuclear war or the destruction of the environment, risk becomes universal: these catastrophes affect everyone, regardless of class, ethnicity, or gender. In addition, risks are institutionalized in specialized organizations for which risk is an underlying principle (such as stock exchanges, insurance companies, sports events, etc.).Finally, apart from the fact that risks arise as the result of the probability of errors in abstract systems for planning, operational management, and control, they also occur as unanticipated results, or as the unforeseen or unintended consequences, of deliberate actions taken to achieve a legitimate public goal. (Martinelli, 2006, p. 143).

The risk of a terrorist attack increases this list of risks, as does experiencing a terrorist threat or the "psychological phenomenon of 'experiencing the threat of a terrorist attack"' through media coverage of ongoing terrorist attacks, information about them on the Internet, and so on (Bykhovets, 2008, p. 6).

Studies show that the intensity of experiencing, for example, a threat of violence or a terrorist attack decreases with increased distance from such events. The specificity of people's reactions to tense, difficult situations is reflected in the reactions of the human psyche and consciousness. In order to pinpoint the specifics of these reactions, we conducted a study using the methodology of "A List of Unpleasant Events," which is designed to study the frequency and subjective strength of the effects of various stressful events. Between 2009 and 2010, two groups of 42 people each were studied; they were 19 to 40 years of age. The first group consisted of 22 women and 20 men, all of whom were taking distance-learning courses at Liberal Arts University. The respondents in the second group (21 women and 21 men) were all employed in municipal companies and health-care organizations in Yekaterinburg. Two categories of events were identified in accordance with the results of the research:

1. The primary unpleasant events were most relevant to the respondents at the time of the study and had the most "weight."

2. The important unpleasant events were also relevant to the respondents, but they were not the cause of various types of disorders, stress, or an overall lower quality of life. 
By analyzing the results of the data on the primary unpleasant events, one can conclude that the respondents had most often been upset, suffering, and experiencing negative emotions in the previous month for the following reasons:

(1) being outdoors in bad weather (an index of 3,249)

(2) suffering from the cold (an index of 3,248)

(3) having insufficient time to spend with a loved one (a spouse, children, or friends) (an index of 2,809)

(4) experiencing physical discomfort (an index of 2,530)

(5) experiencing adversity, failing college exams (an index of 2,436)

Thus, the problems faced by our respondents were basically akin to everyday difficulties, as the first two conditions are related to the objective surroundings and are daily, seasonal phenomena. We should note that these events had nothing to do with terrorist attacks or outbreaks of violence: they were not ethical conflicts or "experiencing the threat of a terrorist attack." It is possible that this result is due to the relatively stable situation in Yekaterinburg and the Sverdlovsk region, and thus the respondents had a greater sense of the importance of their individual health, happiness, interpersonal contacts, and educational success than of terrorist attacks or violence. For the students, the main causes of what were considered to be the "primary unpleasant events" were the inability to devote sufficient time to their families and excessive work, especially during the school year, which caused physical discomfort, while problems with exams and tests were seen only as slightly stressful events, as they were of a temporary, seasonal nature. Both groups of respondents had a clear desire to "take care of themselves" in order to overcome the volatile and negative nature of the situation.

According to the results of the study, events such as the following ones were included in the category of important unpleasant events in the previous month:

1. working on something despite being tired (an index of 2,397 on the scale of "achievements - education - work")

2. getting up early and being disturbed while sleeping (an index of 2,394 on the scale of "health and well-being")

3. conversations with unpleasant people (an index of 2,322 on the scale of "events related to other people")

Thus, the topics the respondents primarily categorized as important unpleasant events were achievements and problems related to work, education, health and well-being, plus unpleasant interpersonal interactions. In addition, all the important unpleasant events were ongoing, which can be interpreted to mean that they caused ongoing social stress that manifested itself in everyday life.

This research shows the relevance of studying the factors, characteristics, and event-related parameters of tense situations and how people experience them. The commonality of the tasks necessary to provide psychological security underlies the need for joint efforts to forestall risks, threats, and stressful situations and to increase the resilience of the social environment." The world that we as a group take for granted is a world of a universal situation, in which universal problems emerge 
in a general perspective that require ordinary solutions using ordinary means to achieve ordinary goals" (Schutz, 2004, p. 627).Tense, extreme situations and threats to psychological security lead to the deformation of an individual's time perspective and provoke sociogenic psychic abnormalities. Social resilience acts as a kind of defensive strategy to ensure personal resilience and the development of personal potential in ongoing, sustained daily activities.

\section{References}

Andreeva, G.M. (1975). Metodologicheskie problemy` razvitija sotcial 'no-psihologicheskogo issledovaniia v USA [Methodological problems of developing of sociopsychological research in the USA]. Metodologicheskie problemy' sotcial 'noi 'psihologii [Methodological problems of social psychology], pp. 269-293. Moscow: Nauka.

Bykhovets, Yu.V. (2008). Concepts held by residents of various Russian regions about terrorist attacks and experiencing a terrorist threat (Abstract of an unpublished doctoral dissertation). Russian Academy of Sciences, Institute of Psychology, Moscow.

Castells, M. (2000). Informatcionnaia e'poha: e'konomika, obshchestvo, kul'tura [The Information Age: Economy, Society, Culture] p. 105, Moscow: Higher School of Economics.

Garfinkel, H. (1963). A conception of, and experiments with, "trust" as a condition of stable concerted actions. In O. J. Harvey (Ed.), Motivation and social interaction: Cognitive determinants, p. 189. New York: Ronald Press.

Habermas, J. (2000). Moral'noe soznanie i kommunikativnoe dei 'stvie [Moral Consciousness and Communicative Action] pp. 100, 161. St. Petersburg, Nauka.

Leontiev, D.A. (2009). Psihologiia kak gymanisticheskaya nauka: ot obazatelnoj distcipliny` $\mathrm{k}$ vozmozhnosti "tcvetushchaia slozhnost' " [Psychology as a Human Science: from discipline of the required to "blooming complexity" of the possible] $v$ Uluchshenie polozheniia psihologii: kriterii i priznaki [In The Advancement of Psychology: Criteria and Features] p. 99. Ed. by A.L. Zhuravlyov, T.D. Martsinkovskaya, A.V. Yurevich. Moscow, Publishing House of the Russian Academy of Sciences Institute of Psychology.

Martinelli, A. (2006). Global 'naia modernizatciia: pereosmy'slenie proekta moderna [Global modernization: Rethinking the project of modernity] (O.V. Malets \& A.V. Rezayev, Trans.) p. 43. St. Petersburg: St. Petersburg University Publishing House.

Pabst, E. (2010). Gosudarstvo osnovannoe na rinke I postdemokratija [The market-based state and postdemocracy] Democratija I modernizatciya: obsyzhdenije vizovov 21 veka [Democracy and modernization: A discussion of the challenges of the 21st century] pp. 231-246. Ed. by V.L. Inozemtsev. Center for Post-Industrial Studies. Moscow: Evropa.

Putin, V. (2012). Byt silnymi: Garantii natsionalnoj bezopasnosti Rossii [Being strong: Assurances of national security for Russia]. Rossiiskaya Gazeta [Russian newspaper] pp. 1-2, 20 February.

Schneier, B. (2008). The psychology of security. Retrieved from http://www.schneier.com/essay155.html (January 21).

Schutz, A. (2004). Izbrannije trudi: Mir svet'ashijs'a smislom [Selected excerpts: A world alight with meaning]. Moscow: ROSSPEN.

Seneca, L. A. (1986). Moralnije pisma k Lutciliju; Tragedii. [Moral letters to Lucilius; Tragedies]. Moscow: Belle Lettres.

Tarabrina, N. V., Bykhovets, Yu. V. (2011). Sovremennoe sostojanie psichologicheskih issledovanij terroristicheskih ugroz. [The current state of psychological research on terrorist 
threats] Medicinskaya psichologiya v Rossii: Naychnij online Zhurnal. [Medical Psychology in Russia: An Online Scholarly Journal] Retrieved from http://medpsy.ru

Vasilyuk, F. E. (1984). Psychologija trudnogo opyta. Analiz sovladanija s criticheskimi sityatcijami [The psychology of difficult experiences. An analysis of ways of handling critical situations] pp. 21-22. Moscow: Moscow University Publishing House.

Chego my boimsya bolshe vsego. Shkala strahov [What We Fear Most of All. A Scale of Fears] (2007). Retrieved from http://psihology.net.ru/chego-my-boimsya-bolshe-vsego-rejtingstraxov

Yemelyanova, T.P. (2009). Socialnye konsepty i simvolicheskoe sovladanie pri perezhivanii travmy, Macropsichologiya sovremennogo Rossijskogo obshestva [Social concepts and symbolic coping when experiencing cultural trauma, The Macropsychology of Contemporary Russian Society,] p. 85. Moscow: Publishing House of the Russian Academy of Sciences Institute of Psychology.

Zinchenko, Yu.P., \& Pervichko, E.I. (2012). The methodology of syndrome analysis within the paradigm of "qualitative research in clinical psychology." Psychology in Russia: State of the Art, 5, 158. doi: 10.11621/pir.2012.0010

Zinchenko, Yu.P., \& Zotova, O.Yu. (2010). Osnovaniya bezopasnosti cheloveka i obshestva [The bases of the security of an individual and society: Monograph.] Moscow: Publishing House of the Academy to Retrain and Improve the Qualifications of Educators.

Received: 20 June 2013

Accepted: 13 September 2013

Available Online: 11 November 2013 